Gi respons på artikler gjennom artiklenes kommentarfelt på tidsskriftet.no.

Innleggene publiseres fortløpende på Tidsskriftets nettside og et utvalg

av innleggene publiseres også i papirutgaven i spalten «Brev til redaktøren».

Redaksjonen forbeholder seg retten til å foreta redaksjonelle endringer.

Forfattere av vitenskapelige artikler har tilsvarsrett, jf. Vancouver-gruppens regler.

\section{Re: Arbeidsbetinget lungekreft i Sør-Trøndelag}

Siri Slåstad og medarbeidere dokumenterer i Tidsskriftet nr. 20/2014 underrapportering av arbeidsbetinget lungekreft, med de konsekvenser dette har i form av tapte rettigheter for den enkelte og tapt kunnskap om risikoforhold (1).

En annen og viktigere side av dette er de tapte mulighetene for tidlig diagnose og behandling for denne pasientgruppen. De seneste tiårs utvikling av diagnostikk basert på computertomografi (CT) og kirurgisk behandling av lungesvulster i tidlig stadium har ikke kommet disse pasientene til gode - i Norge. Dette til tross for arbeidstakeres rettigheter til helseundersøkelser og oppfølging i henhold til Arbeidsmiljølov og forskrifter. Ansvaret for dette ligger hos faglig ansvarlig myndighet (Arbeidstilsyn og Statens arbeidsmiljøinstitutt).

Forekomsten av lungekreft på grunn av asbestpåvirkning er nå på sitt høyeste i landene i Vest-Europa og USA (2). Derfor har ansvarlige myndigheter og institusjoner i disse landene, med Norge som unntak, etablert programmer for helseundersøkelser ved hjelp av CT basert på risiko for arbeidsbetinget lungekreft (eksempler på dette er «SPIRALE-programmet» i Frankrike, og tilsvarende i Sveits, Tyskland og Østerrike i regi av de nasjonale institusjoner for arbeidsskadeforsikring). Det vitenskapelige grunnlaget for risikovurdering og diagnostikk av asbestsykdom finnes i «Helsinkikriteriene». Den seneste oppdatering basert på en internasjonal konferanse i 2014, er nå publisert i Scandinavian Journal of Work, Enviornment and Health $(2,3)$. Her blir det endelig fastslått at lavdose CT bør tilbys arbeidstakere med tidligere eksponering for asbest.

Etableringen av et slikt tilbud i Norge krever handling fra faglig ansvarlig myndighet. Selv om bedriftshelsetjenester vil være et utøvende ledd, er det nødvendig å utvikle retningslinjer for samarbeidende institusjoner og for prioriteringer og dokumentasjon. Passiviteten som hittil har preget myndighetene er ikke lenger bare en faglig og etisk svikt; med Helsinki-kriteriene som norm, har den også fått en erstatningsmessig og strafferettslig side.

\section{Vemund Digernes}

vemu-d@online.no

Vemund Digernes er dr.med., pensjonist og tidligere fagsjef ved Norsk Industri.

Ingen oppgitte interessekonflikter.

Litteratur

1. Slåstad S, Leira HL, Aas 0 et al. Arbeidsbetinget lungekreft i Sør-Trøndelag. Tidsskr Nor Legeforen 2014; 134: 1943-7

2. Vainio H. Epidemics of asbestos-related diseases - something old, something new. Scand J Work Environ Health 2015; 41: 1-4.

3. Wolff H, Vehmas T, Oksa P et al. Asbestos, asbestosis, and cancer, the Helsinki criteria for diagnosis and attribution 2014: recommendations. Scand J Work Environ Health 2015; 41: 5-15.

\section{S. Slåstad og medarbeidere svarer:}

Kollega Vemund Digernes har en interessant kommentar som likevel ligger litt utenfor innholdet og budskapet i vår artikkel. Han tar opp spørsmålet om lungekreftscreening av asbesteksponerte.
Vi mener at når det gjelder screening av asbesteksponerte, tilråder det konsensusdokumentet fra Helsinki som Digernes refererer til (1) snarere forskning etter gitte kriterier med blant annet randomiserte kontrollerte forsøk, enn lavdose CT-screening av alle asbesteksponerte.

Med vår gode oversikt over befolkningen her i landet mener vi det ville være mulig at også Norge kunne delta i internasjonale randomiserte kontrollerte studier med screening av bl.a. asbesteksponerte med lavdose CT av lungene, dersom man på en god måte kunne møte de utfordringer slike screeningstudier byr på. Man må se for seg at dette vil være studier på tvers av flere fagmiljøer som lungemedisin, onkologi, røntgen og arbeidsmedisin.

Det er dessverre ytterst begrenset med midler til arbeidsmedisinsk forskning i Norge. Hvem tar ansvaret? Kunne vi kanskje se for oss et spleiselag mellom næringslivet som har forårsaket asbesteksponeringen, yrkesskadeforsikringen og myndighetene?

\section{Siri Slåstad \\ siri.slastad@stolav.no \\ Bjørn Hilt \\ Oddfrid Aas}

Siri Slåstad (f. 1954) er spesialist i arbeidsmedisin og i lungemedisin og overlege ved Arbeidsmedisinsk avdeling, St.Olavs Hospital.

Ingen oppgitte interessekonflikter.

Bjørn Hilt (f. 1949) er spesialist i arbeidsmedisin, avdelingssjef og professor II i arbeidsmedisin ved NTNU og St.Olavs Hospital.

Ingen oppgitte interessekonflikter.

Oddfrid Aas (f. 1953) er spesialist i arbeidsmedisin og overlege ved Arbeidsmedisinsk avdeling, St.Olavs Hospital.

Ingen oppgitte interessekonflikter.

\section{Litteratur}

1. Wolff H, Vehmas T, Oksa P et al. Asbestos, asbestosis, and cancer, the Helsinki criteria for diagnosis and attribution 2014: recommendations. Scand J Work Environ Health 2015; 41: 5-15.

\section{Re: En rivende utvikling?}

Erlend Hem skriver på lederplass i Tidsskriftet nr. 1/2015 om at mye er ved det samme innen medisinen, på tross av formuleringer som at «det foregår en rivende utvikling» (1). Som vanlig er hans tekst meget lesverdig.

Jeg har likevel lyst til å korrigere en oppfatning av at spesielt ved lungekreft er lite skjedd - et eksempel som ofte brukes. Siden lungekreft står for det største leveårstapet i Norge, er det vesentlig å ha oppdatert informasjon om denne sykdommen (2). Hem skriver at «femårs relativ overlevelse for alle stadier av lungekreft er drøyt $10 \%$, og prognosen er nær uendret de siste 40 år». Ifølge data fra Kreftregisteret (oppgitt på forespørsel) har median overlevelse for kvinner med lungekreft økt fra 7,1 måneder i 2002 til 10,8 måneder i 2012. For menn økte overlevelsen fra 5,4 måneder til 7,9 måneder. Altså en økning på 52\% for kvinner og $46 \%$ for menn. Videre var det i $200217,6 \%$ av kvinner og 14,3\% av menn som var i live to år 
etter lungekreftdiagnosen, mens det i 2012 var henholdsvis $31,5 \%$ og $25,8 \%$ som levde like lenge. Relativ femårsoverlevelse var i $201219,3 \%$ for kvinner og 14,3\% for menn.

Det er mange årsaker til denne bedringen, men trolig har molekylærbiologisk kunnskap frembrakt blant annet gjennom HUGOprosjektet allerede vært bidragsytende (3). Mange av oss har nok en noe mer optimistisk holdning enn Hem til hva som fortsatt kan komme ut av denne type forskning. Selvsagt er det langt frem til at man kan si seg fornøyd med resultatene, men at det har vært en ganske tydelig bedring bare over de siste ti år bør ikke underslås (4). Og ikke minst - denne forbedringen kommer på tross av at en relativt liten andel av kreftforskningsmidlene blir lungekreftpasientene til del, som tydelig vist av Leira i Tidsskriftet nylig (5).

\section{Odd Terje Brustugun}

otr@ous-hf.no

Odd Terje Brustugun (f. 1970) er dr.med. og overlege ved Radiumhospitalet.

Ingen oppgitte interessekonflikter.

\section{Litteratur}

1. Hem E. En rivende utvikling? Tidsskr Nor Legeforen 2015: 135: 101

2. Brustugun OT. Tapte leveår som følge av kreft. Tidsskr Nor Legeforen 2014: 134: 1737

3. Brustugun OT, Helland $\AA$, Fjellbirkeland $L$ et al. Mutasjonstesting ved ikke-småcellet lungekreft. Tidsskr Nor Legeforen 2012; 132: 952-5.

4. Solberg S. Fjellbirkeland L, Brustugun OT. Lyspunkter for lungekreft. Dagsavisen 12.1.2015. http://nyemeninger.no/alle_meninger/cat1003/subcat1015/ thread308198/\#post_308198 (28.1.2015).

5. Leira HO. Mye lungekreft-lite forskning. Tidsskr Nor Legeforen 2014; 134 : $2287-8$

\section{Re: Historie eller historieforvrengning?}

Arne Høiseth har i tidsskriftet nr. 23-24/2014 anmeldt boken «Aging Bones» av Gerald N. Grob i Tidsskriftet (1). Bokanmeldelser er en sjanger med stort rom for subjektivitet, men det er likevel med forbauselse jeg registrerer at det her insinueres at en av nestorene blant USAs medisinhistorikere har begynt med historieforvrengning, og at det er et vel ansett forlag som tilsynelatende har latt ham få begå denne synden. Egen lesing av boken forteller at det er større grunn til å stusse over anmeldelsen enn over boken. Å gi dens potensielle lesere en alternativ anmeldelse er derfor umåtelig fristende.

Boken omhandler i hovedsak to forhold; hvordan osteoporose er gått fra å være en sykdom som rammer noen få til å bli et globalt helseproblem, og hvordan moderne medisin blir til gjennom sosiale prosesser som involverer mange aktører. Den gir i så måte verdifull innsikt for leger som ønsker å forstå utviklingen av eget fag, selv om boken kan kritiseres for å ha et overdrevent amerikansk tyngdepunkt. Historien som fortelles har klare likhetstrekk med den som tidligere er blitt fortalt om andre deler av medisinen der det tilbys kjemisk behandling av risikotilstander (2). Boken er veldokumentert, med over 600 fotnoter som viser til et enda større antall referanser. Den bygger på offentlig tilgjengelige kilder, men mangler den innsideinformasjon anmelderen besitter. $\AA$ insinuere at dette er et verk preget av personlige holdninger, er derfor å underslå bokens kvaliteter.

Anmeldelsen bærer preg av et fokus på detaljer, mens de store linjene oversees. Når fremtidens historie om osteoporose skal skrives, kan det godt tenkes at biomekanikk fortjener en plass, men det er ikke denne kunnskapen som har gjort osteoporose til en global folkesykdom. Det er mulig å innvende at omtalen av FRAX kunne vært mer kritisk. Kalkulatoren omtales imidlertid kun på noen få sider, hvilket ikke nødvendigvis er det inntrykket anmeldelsen gir. At en kritisk omtale av den fort kunne ha vist at det også her finnes sterke bånd til legemiddelindustrien (3), er kanskje ikke den kritikken anmelderen hadde $i$ tankene? I bokens siste setning antyder Grob at bare fremtiden vil vise om osteoporose vil bestå som en legitim medisinsk diagnose, hvilket er noe helt annet enn det synspunkt anmelderen tillegger ham.

\section{John-Arne Skolbekken}

john-arne.skolbekken@svt.ntnu.no

John-Arne Skolbekken (f. 1957) er professor ved Institutt for sosialt arbeid og helsevitenskap, NTNU.

Ingen oppgitte interessekonflikter.

Litteratur

1. Høiseth A. Historie eller historieforvrengning? Tidsskr Nor Legeforen 2014; 134: 2309 .

2. Greene JA. Prescribing by numbers. Drugs and the definition of disease. Baltimore: Johns Hopkins University Press, 2007.

3. Järvinen TLN, Jokihaara J, Guy P et al. Conflicts at the heart of the FRAX tool. CMAJ 2014: 186: 165-7.

\section{Re: Lindrende sedering i livets sluttfase - reviderte retningslinjer}

Dei nye retningslinjene for lindrande sedering i livets sluttfase $(1,2)$, omtalt i Tidsskriftet nr. 3/2015, virkar vel gjennomtenkte, kloke og godt tilpassa dei aller fleste situasjonar som ein kan forventa i livets sluttfase. Eg vil tru at dei aller fleste som arbeider med pasientar i denne livsfasen, her vil finna god rettleiing.

\section{Hans Olav Tungesvik \\ hans.olav@tungesvik.net}

Hans Olav Tungesvik (f. 1936) er psykiatar.

Ingen oppgjevne interessekonfliktar.

\section{Litteratur}

1. Førde R, Materstvedt L J, Markestad T et al. Lindrende sedering i livets sluttfase - reviderte retningslinjer. Tidsskr Nor Legeforen - Publisert først på nett 5 . januar 2015.

2. Retningslinjer for lindrende sedering i livets sluttfase. Oslo: Den norske legeforening, 2014. http://legeforeningen.no/Emner/Andre-emner/Publikasjoner/ Retningslinjer/ (30.1.2015).

\section{Re: Skjerming i akuttpsykiatrien}

Vi leste oversiktsartikkelen til Norvoll og medarbeidere i Tidsskriftet nr. 1/2015 med stor interesse (1). Artikkelen omtaler en stor grad av heterogenitet $\mathrm{i}$ dagens forståelse, klinisk praksis og bruk av tiltaket «skjerming». Mangelen på effektstudier og randomiserte studier påpekes av forfatterne. De konkluderer med at for å kunne endre dagens praksis er det behov for mer forskning. Forfatterne presenterer en oversiktstabell over norske publikasjoner, studier og rapporter. Vi legger merke til at vår rapport 09/2012

fra Kunnskapssenteret (2), om effekt av tiltak for å redusere tvang i psykisk helsevern for voksne ikke er med i denne tabellen.

I vår systematiske oversikt var skjerming inkludert som et av utfallsmålene, fordi skjerming kan innebære tvang. Skjerming (på engelsk «isolation» eller «seclusion») var i liten grad rapportert. Nærmere definisjon og avgrensning av begrepene «isolation» eller «seclusion» manglet også der hvor dette ble undersøkt. Denne 